\title{
Study of structure of high-strength cold-resistant steel after quenching and tempering
}

\author{
P. P. Polteskov, Dr. Eng., Prof., Dept. of Metal Processing Technologyl \\ I. L. Yakovleva, Dr. Eng., Chief Researcher, Laboratory of Physical Metal Science ${ }^{2}$ \\ A. S. Kuznetsova, Dept. of Metal Processing Technology1, e-mail: allakuznetsova.mgtu@mail.ru \\ N. V. Koptseva, Dr. Eng., Prof., Dept. of Casting Processes and Materials Sciencel \\ O. A. Nikitenko, Cand Eng., Associate Prof., Dept. of Metal Processing Technologyl1,e-mail: o.nikitenko@magtu.ru
}

\author{
${ }^{1}$ Nosov Magnitogorsk State Technical University, Magnitogorsk, Russia \\ ${ }^{2}$ M. N. Mikheev Institute of Metal Physics of Ural Branch of RAS, Ekaterinburg, Russia
}

\begin{abstract}
The conditions of heat treatment, providing achievement of high strength characteristics $\left(\sigma_{0,2} \geq 600 \mathrm{~N} / \mathrm{mm}^{2}\right)$ in combination with low-temperature impact strength $\left(\mathrm{KCV}^{-60} \geq 50 \mathrm{~J} / \mathrm{cm}^{2}\right)$ and plasticity $\left(\delta_{5} \geq 17 \%\right)$, were determined for the new weldable sparingly alloyed steel 20G2SMRA. Steel structure was formed after hot rolling, quenching from the temperature $860{ }^{\circ} \mathrm{C}$ and consequent high tempering at the temperature $600{ }^{\circ} \mathrm{C}$ (which determined the obtained complex of steel properties) and then was examined via the method of scanning electronic microscopy. The results of energy-dispersion analysis of carbide particles which were extracted during tempering of quenched steel are presented. It is shown that the required level of strength and cold resistance is provided due to forming of mainly finedispersed lath martensite (with $\alpha$-phase lath width $0.2-0.7 \mu \mathrm{m}$ ) and with small part of residual austenite (about $1 \%$ ), aswellasdislocationhigh-temperaturemartensite. Sub-grain $\alpha$-phasestructure (withsizeofsinglesub-grains $0.1-0.7 \mu \mathrm{m}$ ) and cementite-type of carbide particles are formed during tempering.
\end{abstract}

Key words: weldable high-strength steel, scanning electronic microscopy, mechanical properties, quenching, tempering. DOI: $10.17580 /$ cisisr.2021.02.11

\section{Introduction}

At present time it is expedient to use high-strength weldable structural steels with guaranteed yield strength exceeding $600 \mathrm{MPa}$ for manufacture of lifting and transportation equipment as well as mining machines in Russia and worldwide. Technical and economical efficiency of use of highstrength steels concludes in lowering of mass and increase of constructions bearing capacity, as well as in rise of their service life due to increased strength and cold resistance (down to $-60{ }^{\circ} \mathrm{C}$ ) [1-4].

It was established based on the previously conducted investigations of the new weldable high-strength steel 20G2SMRA with increased cold resistance $[5,6]$, that quenching from the temperature $860{ }^{\circ} \mathrm{C}$ and consequent high tempering at the temperature $600{ }^{\circ} \mathrm{C}$ is the optimal procedure of strengthening heat treatment of rolled sheet metal. The developed technology included processing of sparingly alloyed 20G2SMRA steel [5] and heat treatment procedures [6]; it provided achievement of the complex of properties which meet the requirements in structural strength $\left(\sigma_{0,2} \geq 600 \mathrm{~N} / \mathrm{mm}^{2}\right)$, plasticity and impact strength at low climatic temperatures $\left(-60{ }^{\circ} \mathrm{C}\right)$ of the best foreign analogies. These analogues include Weldox 700 (SSAB, Sweden, EN 10025), Quend 700, Optim 700 QL (Ruukki), shipbuilding steel HY-100, which are delivered after quenching and tempering [7-13].

Study of the structure of rolled sheet metal from the sparingly alloyed 20G2SMRA steel with determination of the required level of strength and cold resistance was the aim of this work.

\section{Materials and methods of the research}

The research was conducted on the rolled sheet samples from the developed 20G2SMRA steel with the following chemical composition (\%, mass.): $0.20 \mathrm{C}, 0.55 \mathrm{Si}, 1.60 \mathrm{Mn}$, $0.005 \mathrm{~S}, 0.012 \mathrm{P}, 0.16 \mathrm{Cr}+\mathrm{Cu}, 0.35 \mathrm{Ni}+\mathrm{Mo}, 0.050 \mathrm{Al}$, $0.005 \mathrm{Ti}, 0.0050 \mathrm{~B}$ [5].

Melting, hot rolling and consequent heat treatment of experimental sheet samples with thickness $15 \mathrm{~mm}$ were conducted on the base of the Scientific and production complex "Engineering center Termodeform-MGTU" and the Center of collective usage of the Scientific and research institute "Nanosteels" at Nosov Magnitogorsk State Technical University.

Examination of steel fine structure, which was formed after quenching from the temperature $860{ }^{\circ} \mathrm{C}$ and consequent high tempering at the temperature $600{ }^{\circ} \mathrm{C}$, was carried out via the method of scanning electronic microscopy (using "Tecnai G2 30 Twin" microscope with GATAN EELS system, equipped with energy-dispersion EDAX spectrometer for elementary analysis and other additional equipment), at accelerating voltage $300 \mathrm{kV}$. To prepare fine foils, the billets were cut in parallel direction of rolling plane, in the middle of a sample thickness. Foils were prepared in accordance with the standard techniques. The microscope software allowed to determine interplane distances of $\alpha, \gamma$ and carbide phases just during observation of foils.

Pattern cutting of rolled sheet samples and processing of their surfaces for testing on extension, hardness, impact bending was conducted according to the requirements of the GOST 7564-97. Extension testing was carried out in accordance with the 
GOST 1497-84 at the universal testing machine of ZWICK $\mathrm{GmbH} \& \mathrm{Co}$. Impact bending testing was executed at the pendulum impact machine RKP 450 on transversal samples with $\mathrm{V}$-shaped notch, after quenching and after quenching with consequent tempering, according to the GOST 9454-78. The samples were cooled down in the LAUDA master PL1 thermostatic cooler to $-60{ }^{\circ} \mathrm{C}$. Microhardness was measured at Buehler Micromet hardness meter according to the GOST $9450-60$ by diamond pyramid indentation with the angle $136^{\circ}$ between the opposite planes, with $1 \mathrm{~kg}$ load; it was determined as an average value of at least 5 measurements.

\section{The results of research}

Flat products from hot-rolled structural steel should be delivered in quenched and tempered state in accordance with the technical specifications. They should meet the following requirements for mechanical properties [14]: tensile strength $\sigma_{\mathrm{B}} \geq 700 \mathrm{MPa}$, yield strength $\sigma_{0,2} \geq 600 \mathrm{MPa}$, relative elongation $\delta_{5} \geq 15,0 \%$, impact strength $\mathrm{KCV}^{-60} \geq 30 \mathrm{~J} / \mathrm{cm}^{2}$. In accordance with these requirements, rolled sheet metal of the examined

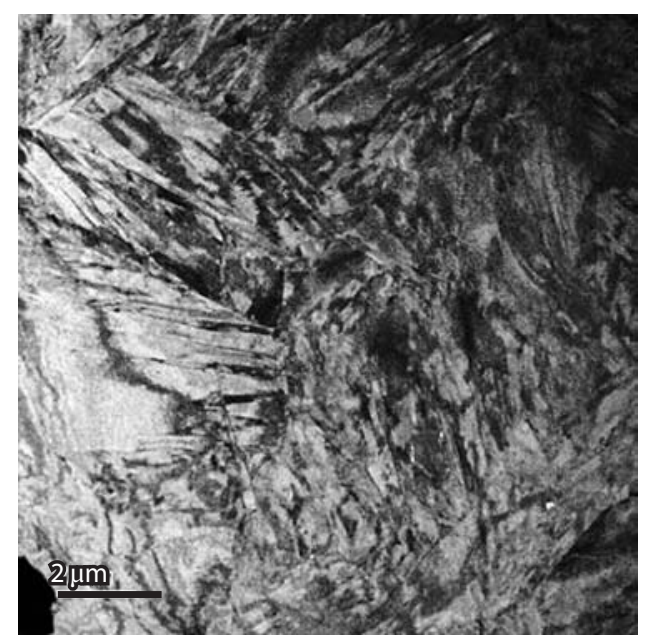

$a$

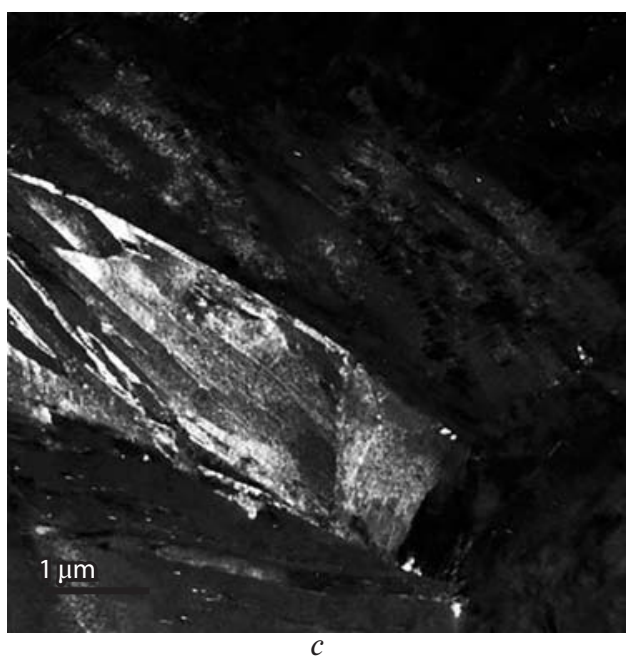

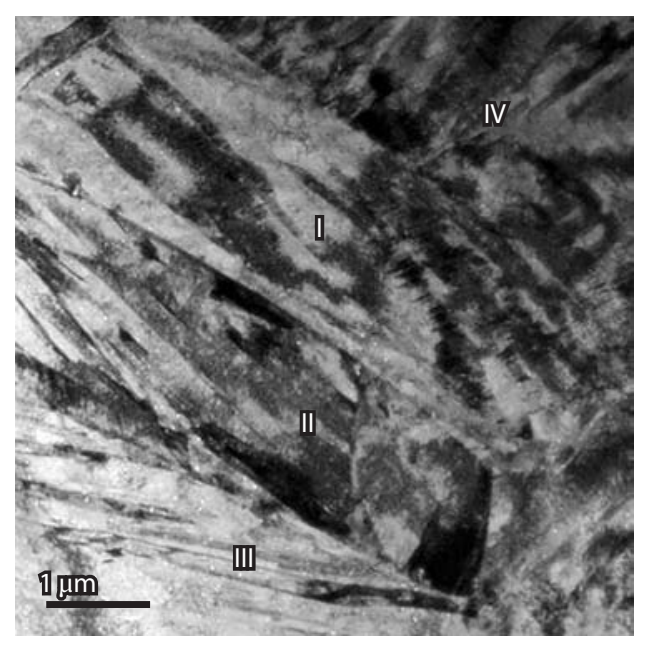

b

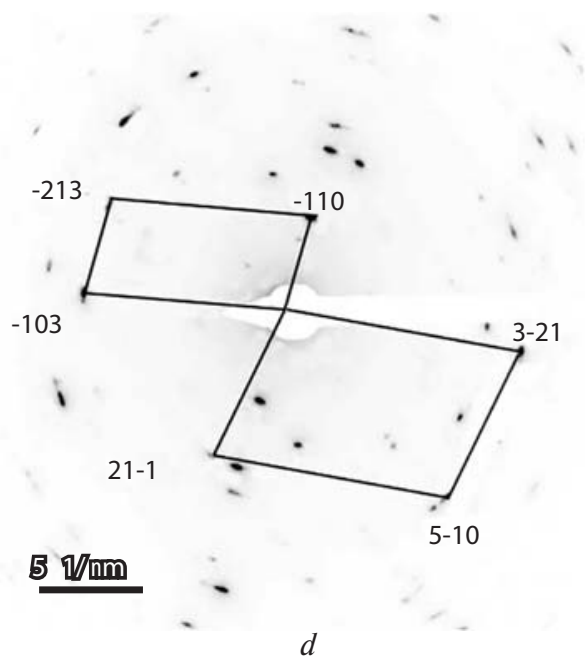

Fig. 1. Microstructure of 20G2SMRA steel after water quenching: $a, b$ - light-field images; $c$ - light-field image in the reflex (110) $\alpha$-phase; $d$ - electron diffraction pattern; the axes of zones [331] and [157] steel should have high strength parameters after heat treatment (first of all - high yield strength) as well as increased values of impact strength at $-60{ }^{\circ} \mathrm{C}$. Providing of such favourable combination of strength and cold resistance makes it possible to use 20G2SMRA steel in constructions which are operated in the Far North conditions.

Examination of fine structure of steel samples after water quenching displayed that fine-dispersed structure of lath martensite is mainly presented in the central part of these samples (Fig. $1 \boldsymbol{a}, \boldsymbol{b}$ ), while volumetric part of martensite exceeds $80 \%$. Width of $\alpha$-phase lathes made $0.2-0.7 \mu \mathrm{m}$. Lathes are collected in packages with square $10-50 \mu \mathrm{m}^{2}$. Number of lathes in a package varies from 4 to 10-12. So, 4 packages can be seen on the Fig. $1 b$. Electron diffraction pattern, which was obtained from this section of the structure containing several packages with lathes of different orientation with the axes of zones [331] and [157], is presented on the Fig. $1 d$. The lathes relating to the package II are displayed in reflected position in a dark field image on the Fig. $1 c$ which was obtained in the reflex (110) $\alpha$-phase. Additionally, layers of residual austenite with thickness $20-40 \mathrm{~nm}$, located at the boundaries of martensite lathes, are enlightened on this image due to proximity of interplane distances of reflexes (011) $\alpha$ and (111) $\gamma$. It can be noted that amount of residual austenite in the structure of quenched sample is rather small and makes about $1 \%$ [6]. Many lathes are divided to the fragments, what is manifested in non-uniform contrast along their length and is connected with elastic distortions of blocks with various dispersity [18].

Microstructure of other sections of the central part of a sample is presented on the Fig. 2 and 3. Azimuth blurring of reflexes on electron diffraction patterns (Fig. $2 d$ and Fig. 3c) testifies on high density of dislocations in lath package martensite $\left(\mathrm{M}_{1}\right)$. Additionally, separate areas of dislocation martensite with optional morpho$\log y\left(M_{0}\right)$ are presented in the structure; their transversal size exceeds the size of lath package martensite (Fig. 2a). These areas are non-structural in their form, they don't contain 


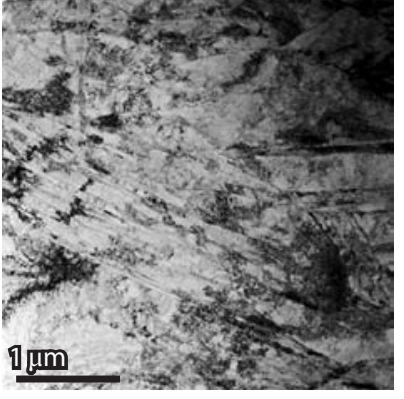

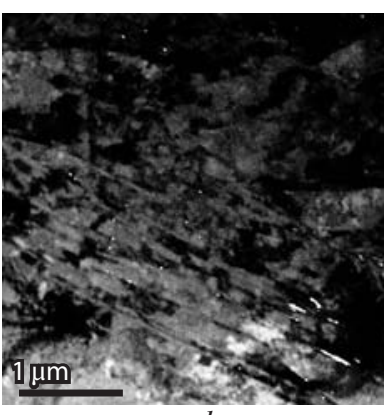

$b$

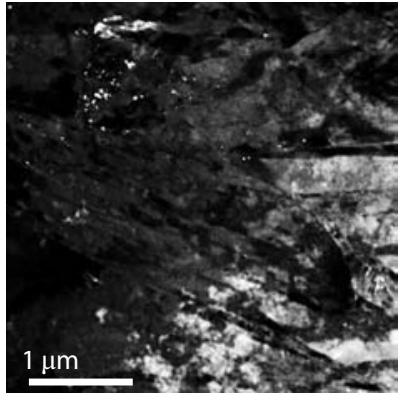

$c$

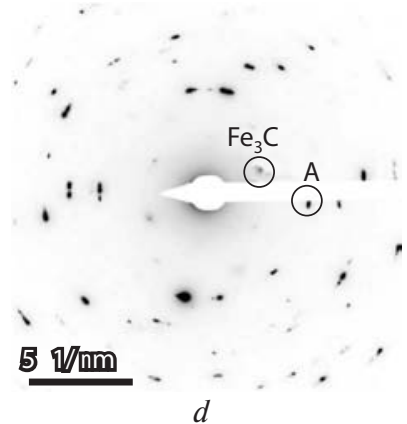

$d$

Fig. 2. Microstructure of 20G2SMRA steel after water quenching: $a$ - light-field image; $b$ - dark-field image in the austenite reflex $(022) \gamma$-phase; $c$ - dark-field image in the reflex $(121)_{\mathrm{Fe}_{3} \mathrm{C}} ; d$ - electron diffraction pattern

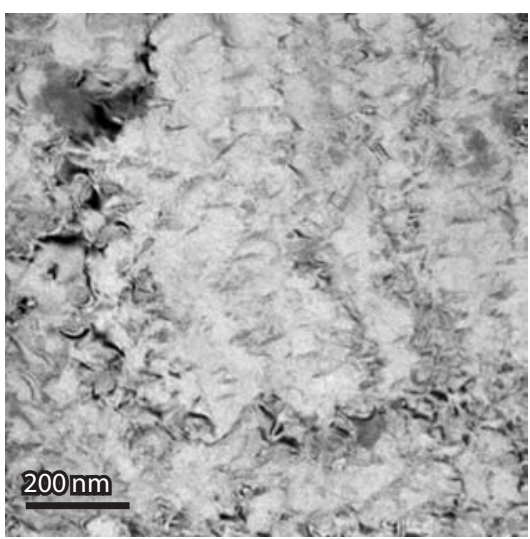

$a$

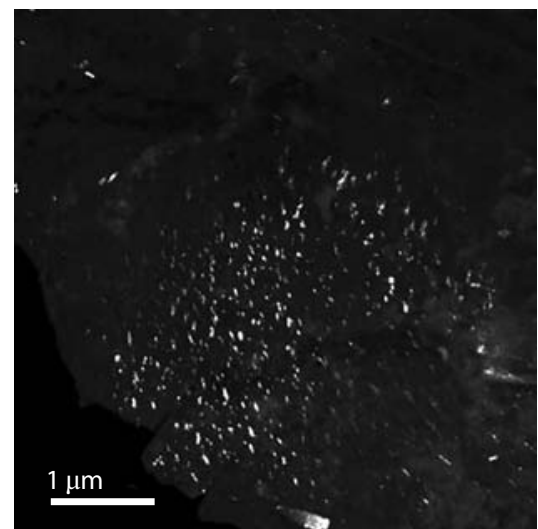

$b$

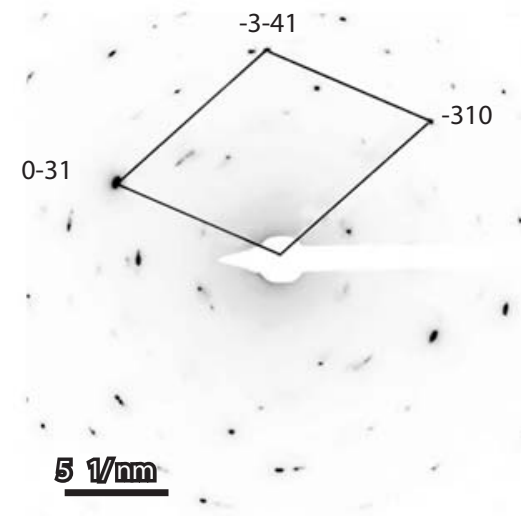

$c$

Fig. 3. Microstructure of 20G2SMRA steel after water quenching: $a$ - light-field image; $b$ - dark-field image in the car bide reflex (103) $\mathrm{Fe}_{3} \mathrm{C} ; c$ - electron diffraction pattern; the axis of zone [139]

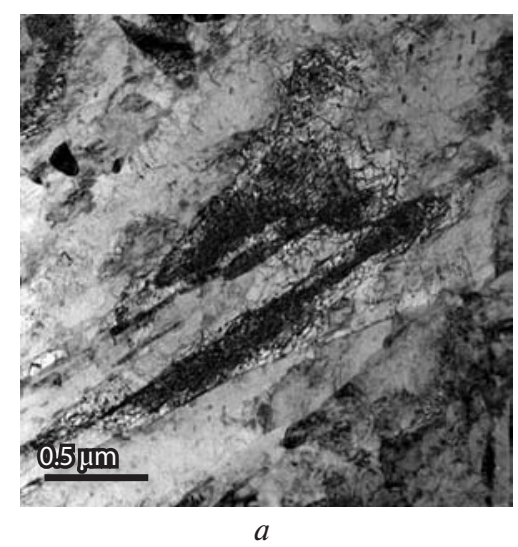

$a$
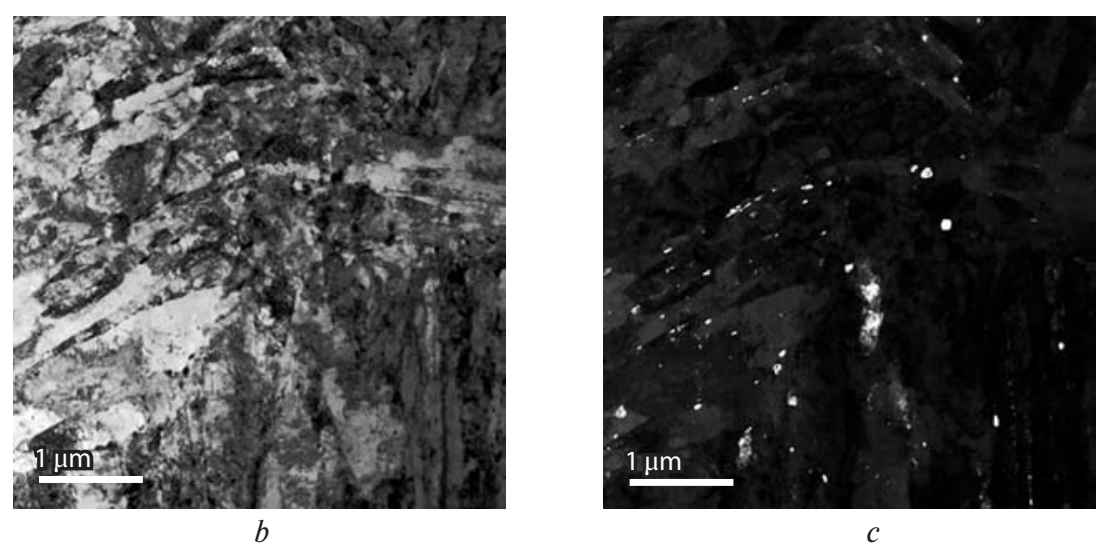

$c$
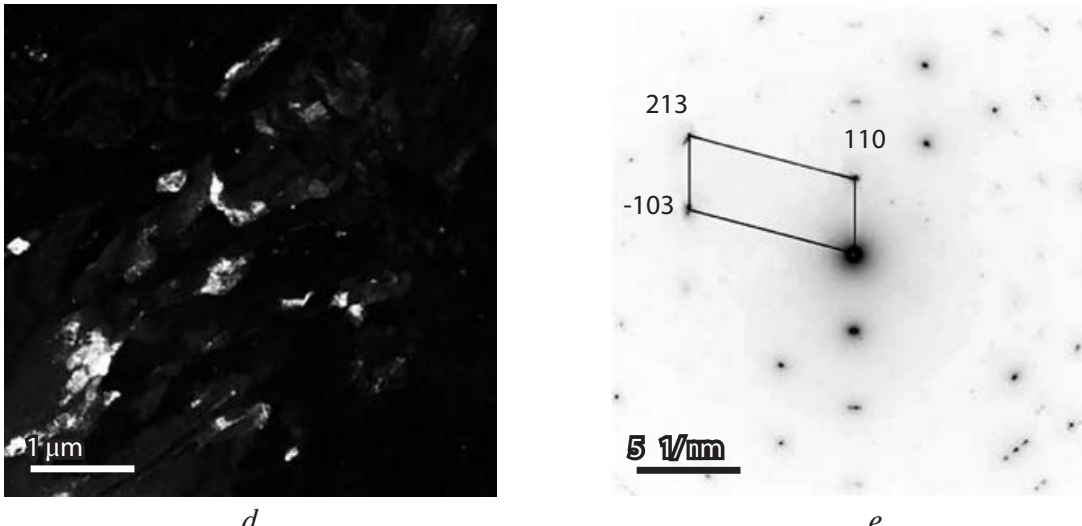

Fig. 4. Microstructure of 20G2SMRA steel after quenching and tempering: $a, b$ - light-field images; $c$ - dark-field image in the reflex of carbide phase $(112)_{\mathrm{Fe}_{3}} ; \dot{ } ; d$ - dark-field image in the reflex of (101) $\alpha$-phase; $e$ - electron diffraction pattern; axis of zone [331] 


\begin{tabular}{|c|c|c|}
\hline \multicolumn{2}{|c|}{ Table 1. Interplane distances of carbide phases [19] } \\
\hline Reflex & $\mathrm{d}, \mathrm{nm}$ & $\mathrm{hkl}$ \\
\hline 1 & 0.2546 & $(020)_{\mathrm{Fe}_{3} \mathrm{C}}$ \\
\hline 2 & 0.2117 & $(121)_{\mathrm{Fe}_{3} \mathrm{C}}$ \\
\hline 3 & 0.3881 & $(103)_{\mathrm{Fe}_{3} \mathrm{C}}$ \\
\hline 4 & 0.2112 & $(121)_{\mathrm{Fe}_{3} \mathrm{C}}$ \\
\hline
\end{tabular}

neither lathes or plates, nor other distinct separation boundaries. Their density of dislocations is smaller than density in package martensite lathes. Such martensite can be identified as dislocation high-temperature martensite [16, 17].

Singular reflexes, which can be related to carbide phase $\left(\mathrm{Fe}_{3} \mathrm{C}\right.$ ) by their interplane distances (Fig. $2 c$ ) can be revealed at electron diffraction patterns (Fig. $2 d$, Fig. $3 d$ ) together with reflexes related to $\alpha$ - and $\gamma$-phases. Local conglomerations of carbide particles are observed in the areas with high-temperature dislocation martensite (Fig. 3). Size of such precipitations makes $10-50 \mathrm{~nm}$, what can be seen on the dark-field image (Fig. $3 b$ ). Interplane distances of separate reflexes were determined via foil examination and are presented on the electron diffraction pattern (Fig. 3d) and in the Table 1. Precipitations of fine-dispersed particles in steel structure took place, evidently, in the cooling process during quenching, as a result of martensite self-tempering.

Thereby, the structure of the sample, which was quenched from $860{ }^{\circ} \mathrm{C}$, consists of lath martensite with small amount of layers of residual austenite, high-temperature dislocation martensite and fine-dispersed particles of carbide phase (cementite), which were extracted during martensite self-tempering. The structure, which was formed during quenching, allowed to provide the following complex of properties: $\sigma_{\mathrm{B}}=1450 \mathrm{MPa}$, $\sigma_{0,2}=1290 \mathrm{MPa}, \delta_{5}=11.5 \%, \mathrm{KCV}^{-60}=39 \mathrm{~J} / \mathrm{cm}^{2}$. In this case, the main input in forming of the yield strength is provided by dislocation, grain boundary and substructure strengthening (based on the data of the works [15-17]). Examination of the steel fine structure after quenching and tempering displayed that lath building of $\alpha$-phase is remained in many areas (Fig. $4 a$ ). Subgrains with misorientation angles $1-5^{\circ}$ are observed within lathes (Fig. 4b). It testifies about passing of dislocations polygonization processes in $\alpha$-phase during tempering, which led to forming subgrain structure that is typical for the initial polygonization stage. Size of separate $\alpha$-phase subgrains makes $0.1-0.7 \mu \mathrm{m}$ (Fig. 4d). Carbides with size 20-100 nm, which were extracted during tempering, are presented on the boundaries of fragments (Fig. 4c). The reflexes which are presented on the electron diffraction pattern, can be related to $\alpha$-phase, carbide phase $\mathrm{Fe}_{3} \mathrm{C}$ (cementite) and, probably, to complicated carbide $(\mathrm{MoFe}){ }_{23} \mathrm{C}_{6}$, having FCC lattice, on the base of dark-field analysis and via interplane distances (Table 2) $[19,20]$. In this case, conduction of energy-dispersion analysis showed that Fe atoms in cementite are partly replaced by Mn atoms (Fig. 5).

Thereby, the sample structure after quenching and high tempering presents subgrain structure containing crystals of $\alpha$-phase and carbide particles of cementite type $\left(\mathrm{Fe}_{3} \mathrm{C}\right.$ and

\begin{tabular}{|c|c|c|}
\hline \multicolumn{3}{|c|}{ Table 2. Interplane distances of $\alpha$-phases and carbide phases [19] } \\
\hline Reflex & $\mathrm{d}, \mathrm{nm}$ & $\mathrm{hkl}$ \\
\hline 1 & 0.2077 & $(011)_{\alpha}$ \\
\hline 2 & 0.2426 & $(112)_{\mathrm{Fe}_{3} \mathrm{C}} \mathrm{Or}(133)_{\left(\mathrm{MoFe}_{23} \mathrm{C}_{6}\right.}$ \\
\hline 3 & 0.2082 & $(011)_{\alpha}$ \\
\hline 4 & 0.1795 & $(212)_{\mathrm{Fe}_{3} \mathrm{C}}$ \\
\hline 5 & 0.1810 & $(202)_{\mathrm{Fe}_{3} \mathrm{C}} \mathrm{Or}(044)_{\left(\mathrm{MoFe}_{23} \mathrm{C}_{6}\right.}$ \\
\hline 6 & 0.1132 & $(466)_{\left(\mathrm{MoFe}_{23} \mathrm{C}_{6}\right.}$ \\
\hline 7 & 0.2427 & $(112)_{\mathrm{Fe}_{3} \mathrm{C}}$ \\
\hline
\end{tabular}

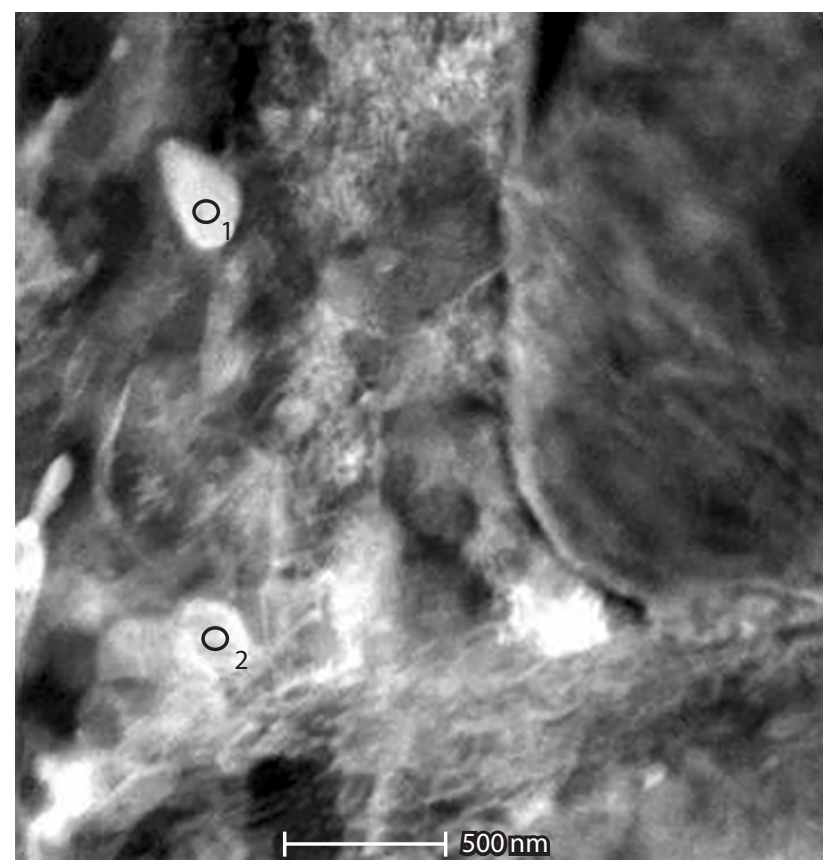

$a$

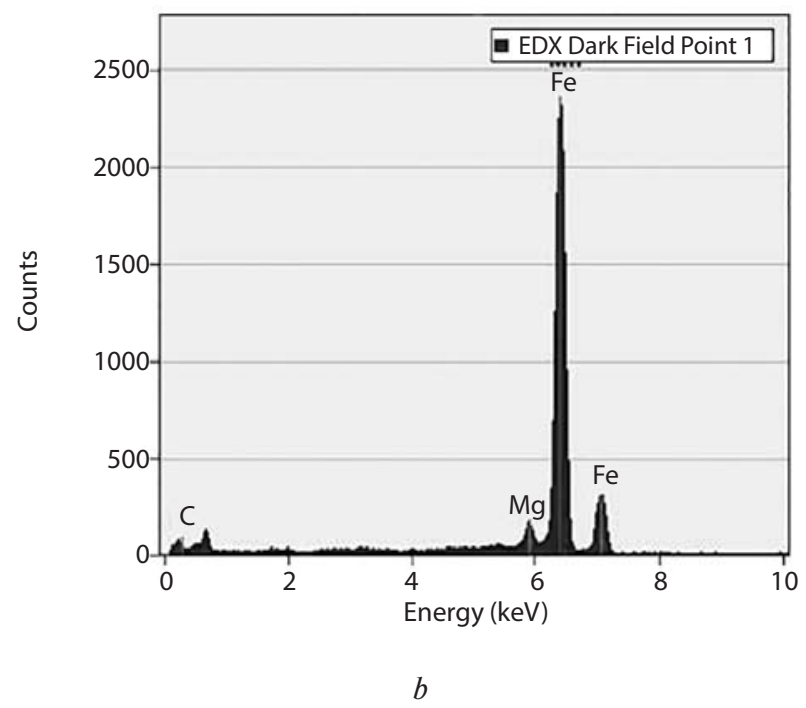

Fig. 5. Microstructure of 20G2SMRA steel after quenching and tempering: $a-$ light-field image of carbide particles; $b$ - carbide 1 spectrum 
$\left.(\mathrm{FeMn})_{3} \mathrm{C}\right)$. Presented structural variations during tempering led to lowering of strength parameters: $\sigma_{\mathrm{B}}=839 \mathrm{MPa}$, $\sigma_{0,2}=769 \mathrm{MPa}$ and elevation of the values of low-temperature impact strength $\mathrm{KCV}^{-60}=64 \mathrm{~J} / \mathrm{cm}^{2}$ and plasticity $\delta_{5}=20 \%$. The obtained results can be explained by separation of lathes into fragments and carbon exit out of the $\alpha$-lattice with forming of dispersed carbides on the boundaries of these fragments [3].

\section{Conclusions}

Investigation of fine structure of the new cold-resistant weldable steel 20G2SMRA with high yield strength was conducted. This steel structure was formed according to the following heat treatment conditions, which were specially developed for it and determined its complex of mechanical properties: water quenching from the temperature $860{ }^{\circ} \mathrm{C}$ and consequent high tempering at the temperature $600{ }^{\circ} \mathrm{C}$.

It was shown that achievement of high strength characteristics $\left(\sigma_{0,2} \geq 600 \mathrm{~N} / \mathrm{mm}^{2}\right)$ in combination with low-temperature impact strength $\left(\mathrm{KCV}^{-60} \geq 50 \mathrm{~J} / \mathrm{cm}^{2}\right)$ is provided owing to forming:

- after quenching - fine-dispersed lath martensite with small layers of residual austenite (in the amount about $1 \%$ ), high-temperature dislocation martensite, as well as nanosized carbides of self-tempering;

- during tempering - subgrain structure of $\alpha$-phase and carbide particles of cementite type.

The research was carried out under financial support of the RF Ministry of Education and Science within execution of the RF President's grant (Agreement No. 075-15-2020205/1 dated 29.03.2021 (int. No. MK-1979.2020.8/1)).

Electron microscope examination of foils for clearance were conducted within the boundaries of the State assignment for the theme "Structure", State reg. No. AAAA-A18-118020190116-6.

\section{REFERENCES}

1. Khlusova E. I., Sych O. V. Creation of cold-resistant structural materials for Arctic region. History, experience, current state. Innovatsii. 2018. No. 11 (241). pp. 85-92.

2. Golubeva M. V., Sych O. V., Khlusova E. I., Motovilina G. D. Study of mechanical properties and destruction features for the new sparingly alloyed cold-resistance steel with guaranteed yield strength $690 \mathrm{MPa}$. Avaitsionnye materialy $i$ tekhnologii. 2017. No. 4 (49). pp. 19-24.

3. Golubeva M. V., Sych O. V., Khlusova E. I. Development of coldresistant weldable steel with strength class $690 \mathrm{MPa}$ for high-duty machines operating in the Arctic conditions. Tyazheloe mashinostroenie. 2018. No. 4. pp. 17-25.
4. Golosienko S. A. New high-strength cold-resistance steels for Arctic application. Proizvodstvo prokata. 2014. No. 2. pp. 17-24.

5. Poletskov P. P., Nikitenko O. A., Kuznetsova A. S., Salganik V. M. The study of transformation kinetics for overcooled austenite of the new high-strength steel with increased cold resistance. CIS Iron and Steel Review. 2020. Vol. 19. pp. 56-59.

6. Poletskov P. P., Kuznetsova A. S., Nikitenko O. A., Alekseev, D. Yu. The study of influence of heat treatment procedures on structure and properties of the new high-strength steel with increased cold resistance. CIS Iron and Steel Review. 2020. Vol. 20. pp. 50-54.

7. Poletskov P. P., Kuznetsova A. S., Alekseev, D. Yu. et al. Analysis of global level of developments in the area of production of hot-rolled high-strength cold-resistance sheet metal with yield strength $\geq 600 \mathrm{~N} / \mathrm{mm}^{2}$. Vestnik Magnitogorskogo gosudarstvennogo tekhnicheskogo universiteta im. G. I. Nosova. 2020. Vol. 18. No. 4. pp. 32-38.

8. High-strength steel Strenx with increased strength. Available at: https://www.ssab.ru/api/sitecore/Datasheet/GetDocument?pro ductId=E2D2EBBB2A144717A0B40944BE5F9FFB\&language $=\mathrm{ru}-\mathrm{RU}$

9. Gliner R. E. Developments in the field of production of highstrength sheet steel in Sweden (steel Domex, Docol, AHSS). Proizvodstvo prokata. 2009. No. 10. pp. 11-18.

10. Aldur ${ }^{\circledR}$ High-strength quenched and tempered fine-grained steels. Available at: https://www.voestalpine.com/stahl/en/content/download/4495/file/Grobblech_TLB_ALDUR\%20500960_DE_0816.pdf

11. Wear-resistant steels for mining of raw materials: [brief report; steels of Dillidur 450 V and Dillimax 690 E grades for metallurgical equipment]. Chernye metally. 2014. No. 3. pp. 102-103.

12. New high-strength structural steel of Ruukki: [brief report; steel of Optim 700 MC Plus grade, Finland]. Chernye metally. 2011. No. 1. pp. 6-7.

13. Porter L. F., Rathbone A. M., Rolfe S. T., Dorshu K. E. Base Materials for Critical Application: requirements for Low Alloy Steel Plate, Forgings, Castings, Shapes, Bars, and Heads of HY 80/100/130 and HSLA 80/100. US Navy, Naval Sea Systems Command, NAVSEA Technical Publication T9074-BD-GIB-010/0300. Original 2002. August. Revision 2. 2012. December. 228 p.

14. Hot-rolled products from structural steel. Part. 6. Technical specification for delivery of flat products made of structural steel with high yield strength, in quenched and tempered state. BS EN 10025-6:2019.

15. Khotinov V. A., Farber V. M. Plasticity evaluation for structural steels by parameters of the uniform stage of extension curve. Materialovedenie. 2021. No. 1. pp. 24-31.

16. Klimashin S. I. Influence of heat treatment on martensite morphology and evolution of defect structure in cast medium-alloyed structural steel. Dissertation for Cand. Eng. Novokuznetsk. 2006. 197 p.

17. Golosienko S. A., Motovilina G. D., Khlusova E. I. Influence of structure formed during quenching on properties of high-strength cold-resistance steel after tempering. Voprosy materialovedeniya. 2008. No. 1 (53). pp. 32-44.

18. Shilyaev P. V., Bogach D. I., Krasnov M. L. et al. Mechanical properties and structural state of rolled sheet made of high-strength wearresistant weldable steel H500 MAGSTRONG. Metallovedenie $i$ termicheskaya obrabotka metalov. 2020. No. 11 (785). pp. 8-12.

19. Andrews C., Dyson D., Keoun S. Electron diffraction patterns and their interpretation. Moscow: Mir. 1971. $256 \mathrm{p}$.

20. Goldshtein M. I., Farber V. M. Dispersion strengthening of steels. Moscow: Metallurgiya. 1979. 208 p. 